\title{
The Role of Muslim Families Awareness in Promoting Education for Human Development in Sokoto State, Nigeria
}

\author{
Hassan Malami Alkanchi \\ Department of Da'wah and Human Development, Academy of Islamic Studies, \\ University of Malaya, 50603 Kuala Lumpur, Malaysia \& \\ Department of Islamic Studies, Umaru Ali Shinkafi Polytechnic, Sokoto, Nigeria. \\ hassanalkanci@gmail.com \\ Yusmini Md Yusoff \\ Department of Da 'wah and Human Development, Academy of Islamic Studies, \\ University of Malaya, 50603 Kuala Lumpur, Malaysia. yusmini@um.edu.my \\ Ashraf Mohammed Zaidan \\ Department of Da'wah and Human Development, Academy of Islamic Studies, \\ University of Malaya, 50603 Kuala Lumpur, Malaysia.dr.ashraf@um.edu.my
}

DOI: https://doi.org/10.22452/usuluddin.vol48no1.7

\begin{abstract}
In Muslim society, the family is an organised institution governed by the principles of Islamic teachings. At the global level, education and human development are considered as universally beneficial for human society as a whole. Muslim families have begun to play a pivotal role in promoting awareness of the importance of education for human development within and beyond their family's context to raise a new level of the importance of education for human development. The objective of this paper is to explore the important roles played by Muslim family awareness on education for human development in Sokoto state, Nigeria. Qualitative methodological approach to data collection and analysis is used in the study. 12 participants were involved, consisting of four (4) for each research subject. Interviews were conducted with family professionals/experts, Muslim family counsellors; Islamic scholars and academicians. The findings of the study reveal that the awareness of Muslim families of education has a positive impact on human development in Sokoto state. Besides that, the study further finds that parents, teachers, and secular/Islamic schools play a pivotal role in promoting human development in Sokoto. Finally, the study offers some implications to help the government, policymakers, stakeholders, religious leaders, and parents to increase awareness of the importance of education for human development. Thus, recommendations from the findings underline the role played by Muslim families on education for human development in Sokoto, Nigeria and elsewhere.
\end{abstract}

Keywords: Muslim family, role, awareness, education, human development 


\section{Introduction}

It is a widely held view that many Muslim families fulfil their duties and responsibilities and play a positive role in supporting education, together with the teachers and educational institutions, following the ethical guidelines of Islamic principles. A considerable number of Muslim families, globally, were already familiar with the teachings and guidelines of the Qur'an and the lifestyle of Prophet Muhammad (SAW). Consequently, they can confidently adhere to the teachings of Islam in terms of moral and ethical conduct that characterize and shape Muslim family life and extend into the social, health, and economic sphere. Thus, the Muslim family as an institution that forms the basis of Islamic education in terms of socialisation, mental and physical health, allows raising the next generation of honest followers of Islam and good citizens. ${ }^{1}$ In the Nigerian context, and Sokoto in particular, Muslim families need to possess both Islamic and secular knowledge with the view to promote professionalism, expertise, wellbeing, and overall human development. They also have to educate their children to become deserving members of society, which is necessary for Muslim family stability, moral values, and human development. ${ }^{2}$

It is in this sense that the importance of Muslim family awareness of education for human development cannot be overemphasised. However, emphasis of the previous studies, has been frequently descriptive and top-down. Very little attention has been paid to empirical evidence generated from primary sources. The few studies that described the role of Muslim families in promoting education are either cautioning on the damaging implication of not been educated, or emphasising the importance of education from the document analysis of secondary data This study is a departure from the stereotypical. It uses semi-structured interviews to explore the role of Muslim family awareness on

1 Muhammad Tahir and Sami Ullah Zubairi, "Towards the Role of Islamic Education in Promoting Peace and Harmony in a Society: An Analysis," Tahdīb al-Afkār, Research Journal of Islamic Studies, Abdul Wali Khan University 4, no. 1 (2017): pp. 25-36.

2 G. Ozdikmenli-Demir and B. S. Kutuk, "The Role of Parents, Siblings, Peers, Relatives and Other Agents in Turkish-Muslim Emerging Adults, Religious Socializations," Archive for the Psychology of Religion-Archiv Fur Religions Psychologie 34, no. 3 (2012): pp. 363-96. 
education for human development in Sokoto state, Nigeria. It is also intended to examine how Muslim family awareness of education impact human development in the context of Sokoto state, Nigeria, and evaluate the influence parents, teachers, and Islamic and secular education has on the Muslim family awareness of education for human development.

\section{Literature Review}

This section presents an extensive literature review on the role of Islamic religious education (IRE) and Islamic religious teachers (IRTs) and the role of parents for human development. Concerning the literature on the role of parents for human development, Ijaz and Abbas observe that the most important role of Muslim parents is to educate their daughters thereby producing an educated society. $^{3}$ In the same way, Ozdikmenli-Demir and Kutuk highlighted that the parent's role focus on transmitting religious values, norms, and practices regulating their behaviour, and sending them to the mosque for worship and teachings. ${ }^{4}$ Likewise, El-Amin examines the role of African-American Muslim parents in choosing schools for their children trying to balance their racial, ideological, and spiritual identities. ${ }^{5}$ Moreover, Supaat and Fa'atin assert that the role of the family is to meet the educational and economic needs, foster unity, cohesion, and adaptability, as well as to promote harmony, and provide financial, physical, emotional, and moral support. ${ }^{6}$

Generally, literature on the role of Islamic religious education (IRE) portrays the IRE system as a source of sincerity and a clear direction to guide, educate, and inculcate discipline in the students

3 A. Ijaz and T. Abbas, "The Impact of Inter-Generational Change on the Attitudes of Working-Class South Asian Muslim Parents on the Education of Their Daughters," Gender and Education 22, no. 3 (2010): pp. 313-26.

4 G. Ozdikmenli-Demir and B. S. Kutuk, "The Role of Parents, Siblings, Peers, Relatives and Other Agents in Turkish-Muslim Emerging Adults, Religious Socializations," pp. 363-96.

5 Aisha El-Amin, "Uncovered: Two Generations of African American Muslim Parents Speak out About Education," Religion \& Education 42, no.3 (2015): pp. 255-67.

6 Supaat and S. Fa'atin, "The Muslim Millennial Family Typology: The Role of Muslim Family Circumflex Model to Avoid Parents' Violent Behavior against Children in Indonesia," Indonesian Journal of Islam and Muslim Societies 9, no. 1 (2019): pp. 57-81. 
and lead them to success. ${ }^{7}$ This is the view of Fakhruddin, Suryadi, Hakam, and Nurdin; ${ }^{8}$ In addition, Salleh and Abd Khahar show that IRE is more of moral education, religious tolerance, affection, humility, dignity, humour, moderation, and understanding. ${ }^{9}$ This is also supported by the view of Kimanen, especially regarding Uswatun Hasanah. ${ }^{10}$

Conversely, Tamuri finds that Islamic religious activities in Islamic schools and universities and school regulations have a positive influence in framing the moral development of students. ${ }^{11}$ This corresponds with the view of Adnan that informal Islamic schools and modern national religious schools play a critical role in educating the young. ${ }^{12}$ While, Pedersen offers that IRE promotes Muslim higher education, especially in the form of Islamic universities they consider as an imperative in today's world, ${ }^{13}$ Agbaria believes that religious authority plays a far more significant role in promoting IRE. ${ }^{14}$ Divergently, Franken observes that funding and co-organising teacher training, and reviewing

7 Ilhaamie Abdul Ghani Azmi, and Nor Raudah Siren, "Job Satisfaction Level of Non-Government Islamic Religious School Teachers," Akademika 88, no. 2 (2018): pp. 35-58.

8 A. Fakhruddin et al., "The Development of Learning Content of Islamic Religious Education (Ire) Courses on Environmental Conservation in Higher Education," 1st UPI International Geography Seminar 2017145 (2018): pp. $1-5$

9 Kamarudin Salleh and Yang Marya Abd Khahar, "Elements of Inter-Religious Understanding in Islamic and Moral Education Curriculum," Islamiyyat-the International Journal of Islamic Studies 38, no. 2 (2016): pp. 111-20.

10 Anuleena Kimanen, "Truth Claims, Commitment and Openness in Finnish Islamic and Lutheran Religious Education Classrooms," Issues in Educational Research 29, no. 1 (2019): pp. 141-57.

11 Ab Halim Tamuri, "Islamic Education Teachers' Perceptions of the Teaching of Akhlaq in Malaysian Secondary Schools," Journal of Moral Education 36, no. 3 (2007): pp. 371-86.

12 Airil Haimi Mohd Adnan, "Being English Teachers in Malaysian Islamic Schools: Identity Narratives from a Five Year 'Life Journey'," Arab World English Journal 8, no. 1 (2017): pp. 220-33.

13 Gry Hvass Pedersen, "The Role of Islam in Muslim Higher Education in India: The Case of Jamia Millia Islamia in New Delhi," Review of Middle East Studies 50, no. 1 (2016): pp. 28-37.

14 A. Agbaria, "Engaging Critically with Religious Authority in Islamic Education a Socio-Theological Perspective on Intellectual Rigidness," Religious Education: Between Radicalism and Tolerance (2018): pp. 203-21. 
curriculum and textbooks, is the best ways for achieving IRE. ${ }^{15}$ It is also the view of Tanjung with the addition of effective mastery of teaching techniques. ${ }^{16}$ Lastly, Shamshiri concludes that for IRE to be rooted in Muslim society, it has to surpass the traditional and secular education system. ${ }^{17}$

Concerning the role of Islamic religious teachers (IRTs), Ismail and Ibrahim reveal that IRTs play a vital role in improving student achievement, providing solutions to existing teaching and learning problems. $^{18}$ Similarly, Jaafar et al. identify that the contributions of IRTs include teaching, confidence, self-ability, effort, and self-efficacy. ${ }^{19}$ This is also the view of $\mathrm{Yagdi}^{20}$ and Fairuzzah, Isa, Khadijah, and Norhapizah with more focus on the nobility of character of teachers, which shape the morals of the students. ${ }^{21}$ In addition to that, Hussin and Tamuri describe that excellent IRTs succeed in embedding core values in their lessons

15 Leni Franken, "Islamic Religious Education in Belgian State Schools: A PostSecular Perspective," Journal of Beliefs \& Values-Studies in Religion \& Education 39, no. 2 (2018): pp. 132-43.

16 Ellisa Fitri Tanjung, "Improving the Quality of Religious Islamic Education Learning through Collaborative Learning Approach in Smp Al-Muslimin Pandan District Tapanuli Tengah," Proceedings of the 5th International Conference on Community Development (AMCA 2018) 231 (2018): pp. 205-7.

17 Babak Shamshiri, "Secular Education or Religious Education in Global Situation: Which One is Suitable for Schools in Islamic Societies," SOCIOINT15: International Conference on Social Sciences and Humanities, (2015): pp. 86-90.

${ }_{18}$ Rozana Ismail and Roslina Ibrahim, "Teachers Perception on Digital Game: A Preliminary Investigation Towards Educational Game Application for Islamic Religious Primary Schools," Proceedings 2018 International Conference on Information and Communication Technology for the Muslim World (ICT4M) (2018): pp. 36-41.

19 Noornajihan Jaafar et al., "The Importance of Self-Efficacy: A Need for Islamic Teachers as Murabbi," International Conference on Education \& Educational Psychology (ICEEPSY 2012) 69 (2012): pp. 359-66.

20 S. Yagdi, "Islamic Religious Education and the Formation of a Pluralistic Habitus. A Critical Discussion within Religious Education," Osterreichisches Religionspadagogisches Forum 26, no. 1 (2018): pp. 61-9.

${ }^{21}$ H. Fairuzzah et al., "Teacher of Noble Characters: Indicators from the Islamic Perspective," WCIT 2014: 2nd World Conference on Islamic Thought \& Civilization, Vols I and II (2014): pp. 469-76. 
and thus assist the learners to develop their personality. ${ }^{22}$ Furthermore, Mohamed, Jasmi, and Zailaini found that IRTs that practiced al-Ghazali's methods of teaching and learning display more care, sincerity, and wisdom. ${ }^{23}$

\section{Muslim Families: Definition and Concept}

Providing an early definition, Ahmad offers that the family institution is a divinely destined institution encouraged by Allah $(S W T)$. He understands the family institution, not as a manufactured or artificially created institution, but rather an ordained institution. Recently, Clark defines the family as an institution where children learn various things that can prepare them to become members of the larger community and prepare them for their future endeavours. ${ }^{24}$ Meanwhile an extended family is that which consists of three or more generations. ${ }^{25}$

\section{The Concept of Education}

Some Muslim thinkers defined the concept of education from an Islamic outlook. For instance, the modern Muslim philosopher and thinker Allamah Iqbal described education as an activity of knowing Allah (SWT) and the self, which is following the position of the famous medieval Muslim philosopher al-Ghazāli who understood education as an activity that enables a person to know God and distinguish between good and bad. Likewise, Alam Kamiz Uddin Ahmed and Muzahid define education as a process through which men, women, young, and old are taught how to contribute to their wellbeing and the welfare of their community. ${ }^{26}$

${ }^{22}$ Nur Hanani Hussin and Ab. Halim Tamuri, "Embedding Values in Teaching Islamic Education among Excellent Teachers," Journal for Multicultural Education 13, no. 1 (2019): pp. 2-18.

23 Sofiah Mohamed, Kamarul Azmi Jasmi, and Muhammad Azhar Zailaini, "Elements of Delivering Islamic Education through Islamic Morality in Several Malaysian Schools," Pertanika Journal of Social Sciences \& Humanities 24, no. 4 (2016): pp. 1267-1277.

${ }^{24}$ M. Reginald Clark, Family Life and School Achievement: Why Poor Black Children Succeed or Fail (Chicago, USA: University of Chicago Press, 2015).

25 Sangeeta Dhami and Aziz Sheikh, "The Muslim Family: Predicament and Promise," Western Journal of Medicine 173, no. 5 (2000): pp. 352.

${ }^{26}$ Kamiz Uddin Ahmed Alam and Mohammad Aman Uddin Muzahid, "Informal Islamic Education and Its Role in Human Resource Development in Society: A Theoretical Evaluation," IIUC Studies 3, no. 1 (2006): pp. 83-92. 


\section{The Islamic Perspective of Human Development}

Chapra postulates that human development according to Islamic principles involves human welfare and wellbeing, incorporates moral excellence, and economic welfare. Likewise, Mirakhor and Askari argue that human development in Islam requires the realisation of human well-being on both facets of human life, materially and immaterially. Thus, cultivating basic human need, individual and societal well-being, human dignity, justice, equality, education, health, equity, increase in wealth and capital are all part of the Shari'ah objectives. Hence, in Islamic ethics, equitable income distribution, elimination of poverty, the provision of material and non-material needs, and the preservation and effective utilisation of natural resources is part of the Islamic principles of human development. This means that human development from an Islamic outlook is not limited to human and economic indicators, economic development, GDP or per-capita income, but rather Islam incorporates all aspects of life through a complete and unified system. ${ }^{27}$

Consequently, the crucial goal of social and economic progress in this light is to provide a complete charter for human development on a broader scale of five objectives of Maqasid alShari'ah; i) spirituality (faith); ii) the preservation of life; iii) education and intellect; iv) the rule of law and justice, and v) economic justice. ${ }^{28}$ This is the reason why Almighty Allah enjoys heads of the families to provide sustenance for those under their care. $^{29}$ Certainly, to achieve human development, the consciousness of Allah (SWT), human welfare, equitable distribution of wealth, and right to education, religious freedom, and social justice need to be in place. ${ }^{30}$

\section{Approach of the Study}

The study adopted a qualitative method design using a case study approach to explore the gigantic role of the awareness of Muslim

See: Surah al-An'ām, 6:38

28 Akilu Aliyu Shinkafi and Nor Aini Ali, "Contemporary Islamic Economic Studies on Maqasid Shari'ah: A Systematic Literature Review," Humanomics 33, no. 3 (2017): pp. 315-34.

29 Surah al-'Alaq, 65:7

30 Surah al-Nisā', 4:135; and Sūrah Șād, 38:26 
family on education for human development in Sokoto state, Nigeria. Purposive sampling technique was used in this study; the participants were selected based on relevance, expertise, and professionalism before the recruitment. The method used for the data collection was verbal in-depth interviews question with the participants. The participants include family professionals/experts, Muslim family counsellors, Islamic scholars and academicians each of the four (4) participants were selected from the research subjects. In all, a total of twelve (12) participants were sampled for the whole study. The method of data analysis employed in this study is thematic and descriptive analysis was used for the analysis and the interpretation of the data. Data from semi-structured interviews were transcribed verbatim and grouped into themes and sub-themes following interpretative phenomenological approach (IPA)'s guidelines.

\section{The Role of Parents in Education for Human Development}

The data that emerged from the responses of the participants revealed that the most important role of Muslim family's awareness (particularly parents) on education for human development includes parental advisory role relating to Islamic and secular education. In this regard, one of the participants related that:

Muslim parents need a better counselling system and awareness, all-encompassing knowledge of religious education that is capable of raising perfect children. The most important thing is to teach the children "the unity of Allah" and His existence (Tawhid) and then focus on educating them by enrolling them in both western and Islamiyah schools. ${ }^{31}$

Similarly, on the advisory role of parents on Islamic religious and secular education another participant reveals that:

I normally advise or counsel my own family and other Muslim families by exhorting them on the significance of seeking knowledge of all disciplines at all times as admonished by the Prophet (SAW). By citing some examples to them to convince them on how knowledge can uplift those who are known among us into ranks in both dunyah and

31 PT: 2 This Interview was conducted on $15 / 01 / 2019$ at College of Administration and Business Studies Sokoto, 10:00am 
a'khirah. I employed strategies ensuring that my child is enrolled in a school where he or she can have a solid Islamic foundation that will help the child to be able to recite the Holy Qur'an and know something about the Sunnah of the Prophet, the Theology, Jurisprudence, and Western Sciences up to University level. ${ }^{32}$

Likewise, the data that emerged from the responses of the participants revealed that parents are aware of their role as educators, concerning the Islamic values, education (' $\mathrm{Ilm}$ ), etc. In this regard, one of the participants related that:

Muslim parents need to be aware that they are the core sponsors of their children's education. This means that they should pay serious attention to the education of their children for effective human development. ${ }^{33}$

Another participant offers that:

My experience with the education of my children is a practical one; this is because; my children have opened up their eyes in the shade of knowledge. Normally, at home, we do have daily Qur'an recitation of one Hizib and morning Du'a immediately after the recitation. We do it after Subhi prayers collectively with my wives and children except those that might be absent for certain unavoidable circumstance. Likewise, we do meet every Wednesday after Magrib and Isha Prayers. We used to study Qur'an, Hadith, Fiqh, Tauheed, Seerah, and Arabic lessons. We also do Question and answer sessions regarding Islamic or Western education. ${ }^{34}$

Another participant reiterated that:

We do have night classes at home from Saturday to Tuesday for teaching our children and those of our neighbours; their Mums and elder sisters in the family are educating them, they also ask for my intervention on certain occasions. At this moment, three of my wives are NCE holders and among our

32 PT: 3 This Interview was conducted on $25 / 01 / 2019$ at Sokoto State Chamber of Commerce Maiduguri Road Sokoto, 12:00pm

33 PT: 6 This Interview was conducted on 25/02/2019 at the participant's Residence Arkilla Federal Low-Cost Area Sokoto, 4:00 pm

34 PT: 5 This Interview was conducted on 16/02/2019 at the participant's Residence Mabera Area Sokoto, 10:00am 
families, we have one male and a female NCE graduate, one undergraduate and one graduate of the law school who is now a qualified senior practitioner at the ministry of justice, Sokoto. Still, others are undergoing their Nursery, Primary, Secondary, and tertiary education.

One of the participants added that:

This is our collective responsibility. We do make every effort to educate our family to the highest level of education within our means, talents, and abilities. This is because; they have the right upon us as parents to educate them and take care of them up to the time they reach the age of puberty or get married when they can support themselves. ${ }^{36}$

Lastly, another participant reveals that:

Honestly speaking, I believe education is key to the annihilation of ignorance in any society. It opens the door of economic buoyancy, social advancement, and civilization. I can spend all that I have to give my children a sound and quality education for the betterment of their future and society in particular. Education is the bedrock of every development, security, and nation-building, and eliminating the hardship for everyone's future. ${ }^{37}$

From the above responses of the participants, the data that emerged reveal that parents are aware of their significant role in educating and the upbringing of their children. They are in charge of their education, moral development, and training and character building. The respondents agreed that Muslim parents considered education as the bedrock of development, security, and nationbuilding, and removing the likely future hardship for everyone.

\section{The Role of Teachers in Promoting Education for Human Development}

The data that emerged from the participants showed that teachers play a significant role in advancing education for human

35 PT: 4 This Interview was conducted on 06/02/2019 at his Residence Mana Alu Quarters Area Sokoto State Time 6:00pm

36 PT: 5 This Interview was conducted on 16/02/2019 at his residence at Mabera area Sokoto State, Time 10:00am

37 PT: 12 This Interview was conducted on 01/04/2019 at Ministry of Religious affairs Sultan Abubakar Road Sokoto, 9:00am. 
development in society by inducing the minds of learners and establishing ethical discipline in schools. In this regard, one of the participants affirmed that:

$\mathrm{We}$, teachers, are at the forefront and the most significant and valuable individuals in developing the anthropological society, influencing the minds of learners, inculcating their moral discipline in schools, and a spiritual and moral guide for students. Right from the beginning, IRT starts their roles with teaching Qur'anic letters and vowels, Tawhid, prayers, given out Zakat, fasting the month of Ramadan and Hajj. At the same time, Muslim Fuqaha (scholars), past and present, have a focus on maintaining their duty towards promoting Islamic values, encouraging religious education and practices, and moral discipline (Tarbiyyah) for human development. ${ }^{38}$

Similarly, one of the participants related that; We, teachers, serve as agents of promoting human values and human development especially, teaching educational activities, character building, and promoting Islamic moral values. Teachers should be aware that they have the potential in promoting Muslim families through teaching and training, inculcating moral behaviour to children, and encouraging the students to be self-determined, goodness to parents, and behave well-mannered. ${ }^{39}$

Additionally, another participant considered Islamic religious teachers as creative problem-solvers, consultants, and peacemakers. The participant supported his view in the following words:

The role of Islamic religious teachers in Muslim society is beyond imparting knowledge. Islamic religious teachers are very resourceful in problem-solving. Many families resort to Islamic religious teachers for the remedy of certain marital problems. They are also consultants of several numbers of families in terms of parenting, Ibadah questions, and answers that are related to religious worship. IRTs are peacemakers of

38 PT: 9 This Interview was conducted on 16//03/2019 at the Department of Education, Usman Danfodio University Sokoto, 12:00pm

39 PT: 4 PT: 4 This Interview was conducted on 06/02/2019 at his Residence Mana Alu Quarters Area Sokoto State, Time 6:00pm 
the society; they solve several problems and conflicts among other families and sometimes the entire community. ${ }^{40}$

One of the participants' highlights that every teacher can be a counsellor to develop the students' personal development in the following words:

Teachers are personality builders and nation builders; they play an essential role in ensuring the character development of children. Teachers and educators contribute a lot towards the character, building the nation and educating children using (the) Islamic educational system and guide them towards attaining best in life, both here and in the hereafter. There is a need for Muslim family awareness regarding the roles of educators in shaping the minds of youth to work diligently for their future development. Briefly, Islamic educators are a strong and powerful vehicle for character building, moral development, and development in all ramifications. $^{41}$

The above assertions from the participants recapitulates the participant's believes that teachers have a significant role in advancing education for human development, instilling Islamic values, encouraging religious education and practices, inducing the minds of learners, and teaching moral-spiritual discipline (Tarbiyyah) in schools. Correspondingly, the data that emerged from the responses of the participants suggested that IRTs are the key persons in the children's life, who teach them the Arabic letters, explain to them the meaning of Tawhid, among others. In addition to that, the participants also agreed that teachers could provide their students with a sense of security, support their personal development, improve their skills, and nurture their talents. Furthermore, the participants pointed to the fact that teachers have proved to be very effective and creative problemsolvers and act as consultants and aid in conflict resolution. Thus, teachers are an integral part of solving the problems of their community, which in turn is an integral part of human development.

40 PT: 10 This Interview was conducted on $22 / 03 / 2019$ at the participant's residence Arkilla Area Sokoto, 3:00pm

41 PT: 1 This Interview was conducted on 01/01/2019 at Sama Road Area Shehu Shagari avenue Sokoto State, Time 11:00am 


\section{The Role of Islamic / Secular Education in Human Development}

Concerning how Islamic and secular education contributes to human development in Sokoto state, one of the participants clarified that:

Generally, Muslim cultures involve the essential practices of attending Islamic schools and following the doctrines of Islam, which is being taught in schools, universities, colleges, Quranic schools (Makarantar Allo), and Islamiyah and western schools around the world. The fundamental pillars of Islam including the act of worship, morality, and spiritual insight, Islamic and societal principles are being taught in these schools. This has significantly contributed to building up humanity, Muslim devotion, and submission to Allah (SWT) with the sharp practices and adherence to the five pillars of Islam (the Shahada, five daily prayers, Zakat, fasting in Ramadan, and Hajj). So, as far as I am concerned, the educational institutions in Sokoto state and those around the world contribute in no small measure in promoting professionalism and expertise, preparing young people for employment, awareness in the act of worship, shaping their mind with perfect education, and sense self-esteem and selfemployment for human development. ${ }^{42}$

Another participant focused on the role of education in securing employment and economic stability for the family by saying that:

Islamic like western education is a source of safeguarding the life of a person in terms of clothing, and shelter, food security, and employment that provides the means for the survival of the entire family members, and their education. Of course, education prepares one for positive reputation, happiness, fame, professionalism, and being a useful member of the society. Quality and effective Islamic and western education changes my family and likely many other Muslim families' around me in terms of shaping their minds towards intellectual development in advancing modern sciences, and recent technologies as per innovations in our contemporary

${ }^{42}$ PT: 8 This Interview was conducted on 10/03/2019 at the Department of Islamic Studies, Sokoto State University, Sokoto, 11:am 
period. I have faith that, both Islamic and western education immensely contributed to making our society intellectually strong. $^{43}$

Another participant noted that:

To me, I do not doubt that agencies of education such as educational institutions and centres, religious and social agencies are some of the sources for promoting effective awareness. This could be through preaching in the public media, religious schools, mosques, special gatherings, palaces, and likely through Jumu'at sermons. Even though these places might not be aware of certain family issues, they are indirectly doing a tedious job that sometimes promotes awareness among Muslim families. Therefore, promoting Muslim family awareness on education is a very essential part of societal intellectual development and above all achievement of human development. ${ }^{44}$

The above data that emerged from the responses of the participants can be interpreted to represent a view that both Islamic and secular education plays a pivotal role in promoting education for human development in Sokoto state, Nigeria. It also showed that Muslim cultures and practices of attending Islamic schools such as universities, colleges, Qur'anic schools, and secular schools promote morality, spirituality, and humanity. Similarly, the participants established that educational institutions in Sokoto succeed in promoting professionalism and expertise, preparing young people for employment, shaping their minds, and nurturing self-esteem for human development.

\section{Discussion of Major Findings}

It is found that previously conducted studies have failed to integrate the role of the Muslim families' awareness, education, and human development and also did not include the role of parents, IRT, and IRE. The outcome concerning the parents indicates that parents have a significant positive influence in

${ }^{43}$ PT: 7 This Interview was conducted on 01/03/2019 venue: Shehu Shagari College of Education Department of Islamic studies Sokoto State Time 9:00 am

44 PT: 4 This Interview was conducted on 06/02/2019 at his Residence Mana Alu Quarters Area Sokoto State Time 6:00pm 
educating their children and providing them with access to religious and secular education. This finding is supported by the view of Supaat and Fa'atin that the role of the family is to provide Islamic knowledge and values that shape the minds and behaviour of their children. ${ }^{45}$ Ozdikmenli-Demir and Kutuk added that the most important role for Muslim parents is transmitting IRE and values, norms, and practices. ${ }^{46}$ Moreover, the findings further reveal that some Muslim parents serve as teachers at the initial level, at home, and are aware of sponsoring their children's education for human development. This outcome is collaborated by Carreno who concluded that the family is the best starting point for human development. ${ }^{47}$

Regarding the teachers, the findings show that teachers also play a significant role in promoting education for human development. They can promote Islamic values, encourage religious practices, shape the minds of their learners, and instil moral and spiritual discipline (Tarbiyyah) in schools for human development. This finding is in line with the view of Jaafar et al. who concluded that among the roles of IRTs are instructing the subject contents, building confidence, self-reliance, and selfefficacy. ${ }^{48}$ The findings further show that teachers have the opportunity to support the students' physical, social, economic, intellectual, emotional, and spiritual development by letting them experience a stronger sense of security, acquiring new skills and discovering their talents. These findings are validated by the view of Tamuri that teaching moral values allows students to develop a holistic individual personality by following a balanced and integrated approach that encompasses the intellectual, spiritual, emotional, and physical aspects of personal development. ${ }^{49}$ Lastly,

45 Supaat and S. Fa'atin, "The Muslim Millennial Family Typology: The Role of Muslim Family Circumflex Model to Avoid Parents' Violent Behavior against Children in Indonesia," pp. 57-81.

46 G. Ozdikmenli-Demir and B. S. Kutuk, "The Role of Parents, Siblings, Peers, Relatives and Other Agents in Turkish-Muslim Emerging Adults, Religious Socializations," pp. 363-96.

47 Cigdem Kagitcibasi, Family, Self, and Human Development Across Cultures: Theory And Applications (n.p.: Routledge Classic Editions, 2017).

48 Noornajihan Jaafar et al., "The Importance of Self-Efficacy: A Need for Islamic Teachers as Murabbi," pp. 359-66.

49 Ab Halim Tamuri, "Islamic Education Teachers' Perceptions of the Teaching of Akhlaq in Malaysian Secondary Schools," n.p. 
the result also suggests that most teachers are effective problemsolvers and assist families by offering advice and guidance in personal matters. In short, teachers act as counsellors, personal coaches, moral guides, and nation builders. This outcome is supported by the finding of Fairuzzah et al, whereby the upright and noble character of the teachers allows them to shape the morals of their students and initiate them into the existing system of belief, faith, culture, norms, and values. ${ }^{50}$

The outcome of the study further confirms that both secular and Islamic types of education play an important role in promoting education for human development in Sokoto state, Nigeria. The participants further agreed that the educational institutions in the Sokoto state encourage the acquisition of knowledge, professionalism, skills, and expertise and thus adequately prepare young people for employment as part of human development. This outcome coincides with the findings of Adnan (2017) that religion and government schools both play a critical role in educating the young generation of Malaysian Muslims.

\section{Implications of the Study}

This study implores:

o The Sokoto state government to sponsor more awareness campaigns, effective training, and development courses for the teachers to raise their level of professionalism and expertise, and providing additional family counselling centres handled by the family experts to guide the Muslim public in family education, and parentage, for human development.

$\circ$ The NGOs, Muslim families, family counsellors, Muslim scholars, family experts, policymakers, stakeholders, and Islamic education practitioners, and academicians to collaborate for further family counselling strategies.

$\circ$ Parents towards focussing on both types of education (religious and secular) and support their children in terms of sponsoring the education of their children, moral and character training, and intellectual growth for achieving human development.

50 Fairuzzah et al., "Teacher of Noble Characters: Indicators from the Islamic Perspective," pp. 469-76. 


\section{Conclusion}

This article constitutes a piece of original research that highlights the role of Muslim family awareness of education for human development in Sokoto state, Nigeria. The research questions designed for the study include how the Muslim families' awareness of education influences human development in Sokoto state, Nigeria. Also examined is the responsibility of parents, teachers, schools, and IRE. From the above outcome and discussion, the findings of the study conclude that Muslim families especially parents in Sokoto state are aware of the importance of education and its impact on human development. Besides that, it is found that parents, teachers, secular and Islamic schools, play a pivotal role in promoting human development in Sokoto state. It is proposed that further research should examine the role of the above-mentioned groups separately. This study is hoped to serve as a useful reference for the Muslim public in general, the Sokoto state government, NGOs, schools, teachers, family experts/counsellors, policymakers, stakeholders, and Islamic education practitioners.

\section{References}

A. Fakhruddin et al. "The Development of Learning Content of Islamic Religious Education (Ire) Courses on Environmental Conservation in Higher Education." 1st UPI International Geography Seminar 2017145 (2018): pp. 1-5

Ab Halim Tamuri. "Islamic Education Teachers' Perceptions of the Teaching of Akhlaq in Malaysian Secondary Schools." Journal of Moral Education 36, no. 3 (2007): pp. 371-86.

Agbaria, A. "Engaging Critically with Religious Authority in Islamic Education a Socio-Theological Perspective on Intellectual Rigidness." Religious Education: Between Radicalism and Tolerance (2018): pp. 203-21.

Airil Haimi Mohd Adnan. "Being English Teachers in Malaysian Islamic Schools: Identity Narratives from a Five Year 'Life Journey'." Arab World English Journal 8, no. 1 (2017): pp. 220-33.

Alam, Kamiz Uddin Ahmed and Muzahid, Mohammad Aman Uddin. "Informal Islamic Education and Its Role in Human 
Resource Development in Society: A Theoretical Evaluation." IIUC Studies 3, no. 1 (2006): pp. 83-92.

Babak Shamshiri. "Secular Education or Religious Education in Global Situation: Which One is Suitable for Schools in Islamic Societies." SOCIOINT15: International Conference on Social Sciences and Humanities (2015): pp. 86-90.

Clark, M. Reginald. Family Life and School Achievement: Why Poor Black Children Succeed or Fail. Chicago, USA: University of Chicago Press, 2015.

El-Amin, Aisha. "Uncovered: Two Generations of African American Muslim Parents Speak out About Education." Religion \& Education 42, no.3 (2015): pp. 255-67.

Ellisa Fitri Tanjung. "Improving the Quality of Religious Islamic Education Learning through Collaborative Learning Approach in Smp Al-Muslimin Pandan District Tapanuli Tengah." Proceedings of the 5th International Conference on Community Development (AMCA 2018) 231 (2018): pp. 205-7.

Franken, Leni. "Islamic Religious Education in Belgian State Schools: A Post-Secular Perspective." Journal of Beliefs \& Values-Studies in Religion \& Education 39, no. 2 (2018): pp. 132-43.

H. Fairuzzah et al. "Teacher of Noble Characters: Indicators from the Islamic Perspective." WCIT 2014: 2nd World Conference on Islamic Thought \& Civilization I \& II (2014): pp. 469-76.

Ijaz, A. and Abbas, T. "The Impact of Inter-Generational Change on the Attitudes of Working-Class South Asian Muslim Parents on the Education of Their Daughters." Gender and Education 22, no. 3 (2010): pp. 313-26.

Ilhaamie Abdul Ghani Azmi, and Nor Raudah Siren. "Job Satisfaction Level of Non-Government Islamic Religious School Teachers." Akademika 88, no. 2 (2018): pp. 35-58.

Kagitcibasi, Cigdem. Family, Self, and Human Development Across Cultures: Theory And Applications. N.p.: Routledge Classic Editions, 2017.

Kamarudin Salleh and Yang Marya Abd Khahar. "Elements of Inter-Religious Understanding in Islamic and Moral Education Curriculum." Islamiyyat-the International Journal of Islamic Studies 38, no. 2 (2016): pp. 111-20. 
Kimanen, Anuleena. "Truth Claims, Commitment and Openness in Finnish Islamic and Lutheran Religious Education Classrooms," Issues in Educational Research 29, no. 1 (2019): pp. 141-57.

Muhammad Tahir and Sami Ullah Zubairi. "Towards the Role of Islamic Education in Promoting Peace and Harmony in a Society: An Analysis." Tahdīb al-Afkār, Research Journal of Islamic Studies, Abdul Wali Khan University 4, no. 1 (2017): pp. 25-36.

Noornajihan Jaafar et al. "The Importance of Self-Efficacy: A Need for Islamic Teachers as Murabbi." International Conference on Education \& Educational Psychology (ICEEPSY 2012) 69 (2012): pp. 359-66.

Nur Hanani Hussin and Ab. Halim Tamuri. "Embedding Values in Teaching Islamic Education among Excellent Teachers." Journal for Multicultural Education 13, no. 1 (2019): pp. 2-18.

Ozdikmenli-Demir, G. and Kutuk, B. S. "The Role of Parents, Siblings, Peers, Relatives and Other Agents in Turkish-Muslim Emerging Adults, Religious Socializations." Archive for the Psychology of Religion-Archiv Fur Religions Psychologie 34, no. 3 (2012): pp. 363-96.

Pedersen, Gry Hvass. "The Role of Islam in Muslim Higher Education in India: The Case of Jamia Millia Islamia in New Delhi." Review of Middle East Studies 50, no. 1 (2016): pp. 2837.

Rozana Ismail and Roslina Ibrahim. "Teachers Perception on Digital Game: A Preliminary Investigation Towards Educational Game Application for Islamic Religious Primary Schools." Proceedings 2018 International Conference on Information and Communication Technology for the Muslim World (ICT4M) (2018): pp. 36-41.

Sangeeta Dhami and Aziz Sheikh. "The Muslim Family: Predicament and Promise." Western Journal of Medicine 173, no. 5 (2000): pp. 352.

Shinkafi, Akilu Aliyu and Nor Aini Ali. "Contemporary Islamic Economic Studies on Maqasid Shari'ah: A Systematic Literature Review." Humanomics 33, no. 3 (2017): pp. 315-34.

Sofiah Mohamed, Kamarul Azmi Jasmi, and Muhammad Azhar Zailaini. "Elements of Delivering Islamic Education through 
Islamic Morality in Several Malaysian Schools." Pertanika Journal of Social Sciences \& Humanities 24, no. 4 (2016): pp. 1267-1277.

Supaat and Fa'atin, S. "The Muslim Millennial Family Typology: The Role of Muslim Family Circumflex Model to Avoid Parents' Violent Behavior against Children in Indonesia." Indonesian Journal of Islam and Muslim Societies 9, no. 1 (2019): pp. 57-81.

Yagdi, S. "Islamic Religious Education and the Formation of a Pluralistic Habitus. A Critical Discussion within Religious Education." Osterreichisches Religionspadagogisches Forum 26, no. 1 (2018): pp. 61-9. 